\title{
Abundance and diversity of reef fish larvae in Mabahiss Bay, on the Egyptian Red Sea coast
}

\section{Mohammed A. Abu El-Regal ${ }^{1 *}$; Mohammed M. Abu Zeid ${ }^{2}$; Ahmed M. Hellal ${ }^{2}$ and Mahmoud M. Maaty ${ }^{3}$ \\ 1- Marine Science Department, Faculty of Science, Port Said University, Port Said, Egypt.}

2- Zoology Department, Faculty of Science, Al-Azhar University, Cairo, Egypt.

3- National Institute of Oceanography and Fisheries, Hurghada, Red Sea, Egypt M_abuelregal@yahoo.com

\section{ABSTRACT}

The larvae of coral reef fishes have been studied in order to determine the composition of fish larval community in Mabahiss bay located at Hurghada on the Egyptian Red Sea coast. Fish larvae were collected monthly from November 2012 to October 2013 by plankton net of $0.5 \mathrm{~mm}$ mesh size.

A total of 1336 fish larvae comprising 57 fish taxa were recorded from all habitats. The highest number of larvae (517) was collected from the open water areas, whereas the lowest of 129 larvae were taken from seagrass areas. The highest number of species was recorded from the open water areas (39 taxa), while the lowest number of species was taken from the seagrass area (19 taxa).

Results obtained from the present study reflect the importance of different Red Sea habitats to the early life history of reef fishes and how they could support these stages.

Keywords: reef fish, larvae, habitats, spatial distribution, Red Sea

\section{INTRODUCTION}

Fishes are the heart of the coral reefs and constitute a dominant component of the reef fauna. (Abu El-Regal, 2014). Ichthyoplankton of reef fishes in the Red Sea is poorly studied compared to that in other Indo-Pacific areas such as Great Barrier Reef. This may be largely due to the difficulties in sampling and identification of these small stages. Despite the extensive work on the adult fish fauna in the area, a few studies have been carried out on the early stages of reef fish in the Egyptian waters (Abu El-Regal, 1999; Faroukh, 2001; Abu El-Regal, 2008; Abu El-Regal et al., 2008a; Abu El-Regal, 2009; Abu El-Regal, 2012, 2013a \& b and 2014).

Larval abundance could be good index for the success of generations. Data about where and when eggs and larvae are abundant can be used to detect the spawning grounds and the spawning seasons of the commercially important fishes (Smith \& Richardson, 1977; Fuiman and Warner, 2002) that could be applied to determine the closing seasons and the closed areas (Abu El-Regal, 2009).

They also serve to estimate the spawning stock, the spawning seasons, spawning grounds, and nursery ground of the commercial fishes. Determining the abundance of eggs and larvae in an area is usually less expensive to do than sampling the adults because it is possible to sample several species over broad areas with simple plankton net. Besides, the plankton samples contain not only the fish larvae but also part of their potential zooplanktonic prey and predator (Smith \&Richardson, 1977, Abu ElRegal. et al, 2008b). 
There has been explosive growth in research on early life of fishes over the past 40 years (Rutherford, 2002; Pattira et al., 2012). It is now clear that information derived from the fish eggs and larvae makes a number of unique contributions to fishery sciences that are crucial for accurate assessment and management of fish populations (Fuiman and Werner, 2002; Abu El-Regal, 2013b).

Distribution of fish larvae in the coral reef has received more attention than any other aspect of their biology because distribution is probably the most easily studied for the pelagic stage at least for smaller larvae (Leis, 1991a). The distribution of fish larvae can be determined by spawning behavior and spawning grounds of the adult, topography of the reef, duration of larval period, behavior of the larvae and the growth and mortality of the larvae (Cushing, 1990; Leis, 1991a; Lazzari, 2001; Leis et al., 2006; Montgomery et al., 2001, Abu El-Regal, 2008b).

Few studies have been conducted on the larvae of the Egyptian Red Sea (Abu El-Regal, 1999; Abu El-Regal et al, 2008a \& b; Abu El-Regal, 2009; Abu El-Regal, $2013 \mathrm{a} \& \mathrm{~b})$

This work aimed to study the distribution of the larval stages of reef fishes in different habitats of the Egyptian Red Sea coast at Hurghada; and the importance of these habitats to the early life history of reef fishes.

\section{MATERIAL AND METHODS}

\section{Study area (Mabahiss bay)}

Mabahiss bay is characterized by the presence of different habitats that represent the tropical habitats in the Red Sea. With the exception of mangroves, the bay has coral reefs, seagrasses, sandy shores and shallow lagoons. Sampling processes were carried out in three habitats inside the bay (coral reefs, seagrasses and shallow lagoons) and one habitat outside the bay (open waters) (Fig. 1).

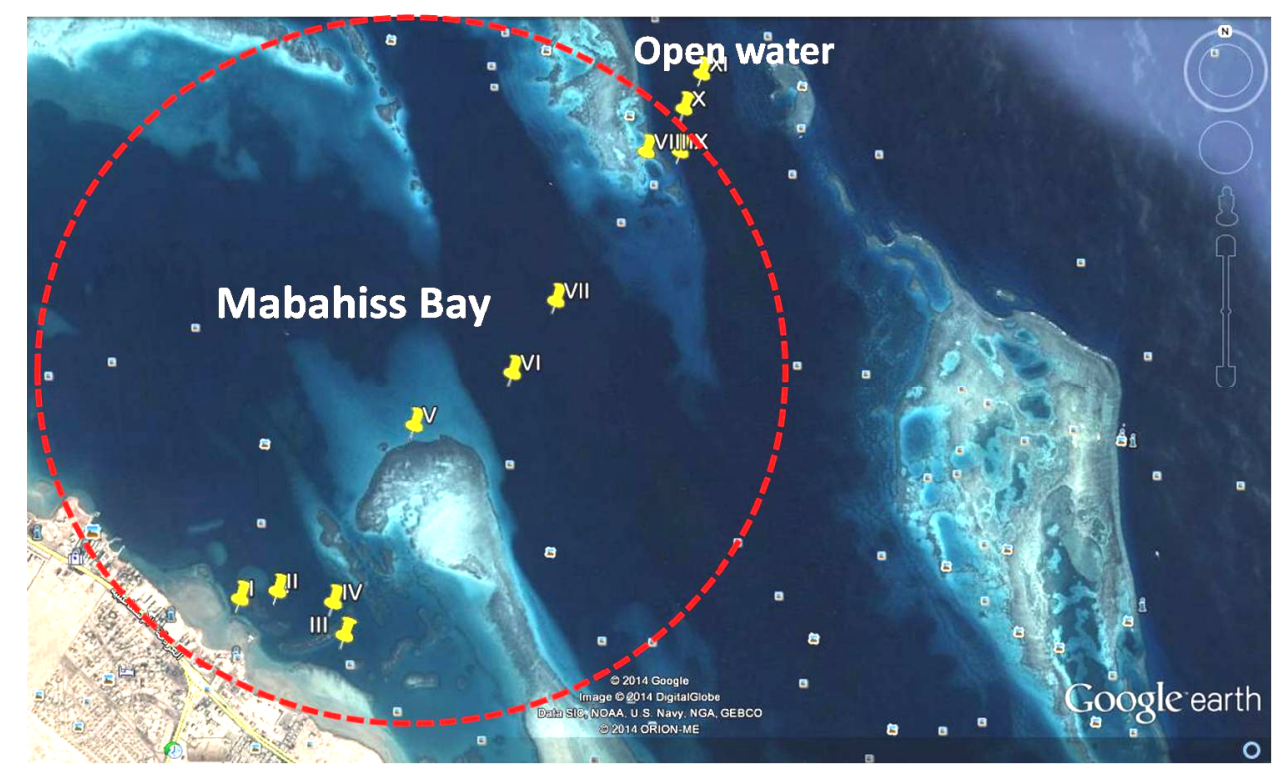

Fig. 1: Study area and sampling sites in Mabahiss bay

\section{Sampling and preservation}

Ichthyoplankton samples were monthly taken from November 2012 to October 2013, using a $50 \mathrm{~cm}$ mouth diameter and $0.5 \mathrm{~mm}$ mesh size plankton net provided with a flowmeter to calculate the volume of water filtered. Nets were towed 
horizontally at $1 \mathrm{~m}$ depth parallel to the coast with a towing speed of 1.5 knots and a towing duration of 5-10 minutes. Three replicates were taken and the mean abundance and mean volume of water filtered were calculated. A total of 528 samples were taken in the early morning just before sunrise. The samples were preserved on board in buffered 5\% formalin seawater for further analysis.

\section{Laboratory procedures}

Plankton samples were sorted and examined under Nikon and Optika stereomicroscopes and fish larvae were identified to the highest possible taxonomic level using the available guides (Leis and Rennis, 1983; Abu El-Regal, 1999; Leis and Carson-Ewrat, 2002; Abu El-Regal, 2008a; Abu El-Regal, 2012). Based on the size and development of the notochord, larvae were divided into preflexion, flexion and postflexion; and the flexion larvae were included in the postflexion larvae.

\section{Data analysis}

The univariate statistics were done in SPSS v.17.0, using ANOVA to determine differences in the number of individuals and number of species between months and sites. All data were tested for homogeneity of variance and where the samples were not homogeneous, data were either logarithmically or square root transformed or the non-parametric Kruskal-Wallis test was used (Zar, 1999; Dytham, 2003).

The cluster analysis and diversity indices, richness, evenness and diversity were calculated using PRIMER (Plymouth Routines in Multivariate Ecological Research) v 5. Relative abundance of fish larvae was calculated as number larvae of each fish taxon divided by the total number of fish larvae collected. Larvae was divided according to relative abundance as follows; rare $0-0.1$; frequent $0.1-1$; common $1-10$, abundant 10-20 and dominant $>20$.

\section{RESULTS}

\section{Abundance of fish larvae}

A total of 1336 larvae were collected from the all sites throughout a year of sampling, representing 57 species and 40 families belonging to 13 orders of fish. Most of the larvae could be identified to different taxonomic levels; 18 taxa were identified to species, 4 taxa to genus and 34 taxa as family. Approximately, $4 \%$ of the collected larvae could not be identified (Table 1). Of the four surveyed habitats, open water areas located outside the bay had the highest number of fish larvae with 517 individuals $/ 1000 \mathrm{~m}^{3}(38.7 \%$ of all larvae collected) whereas, the seagrasses had the lowest number of larvae with $129 / 1000 \mathrm{~m}^{3}$ forming $9.7 \%$ of all larvae (Figs., $2 \& 3$ ).

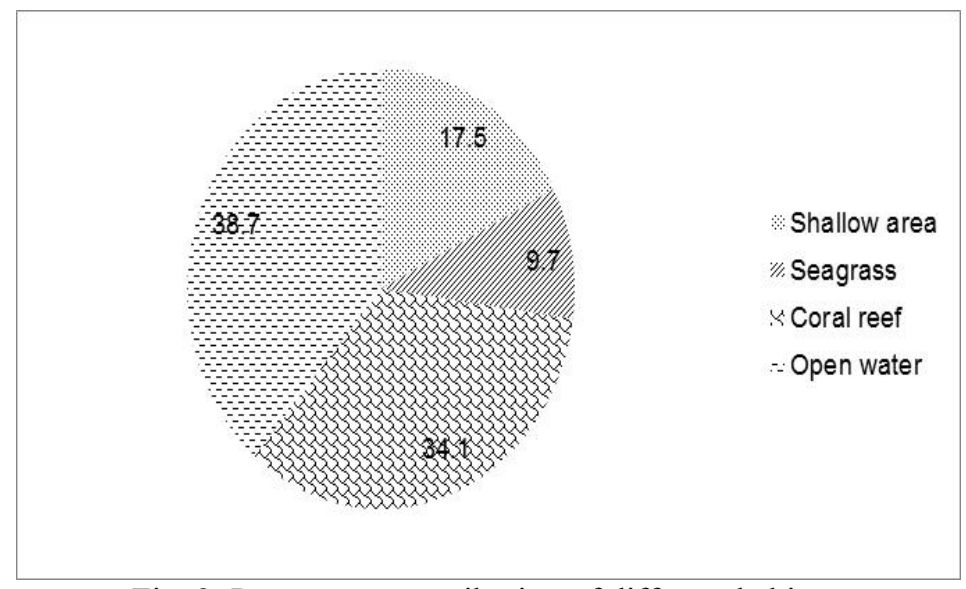

Fig. 2: Percentage contribution of different habitats 


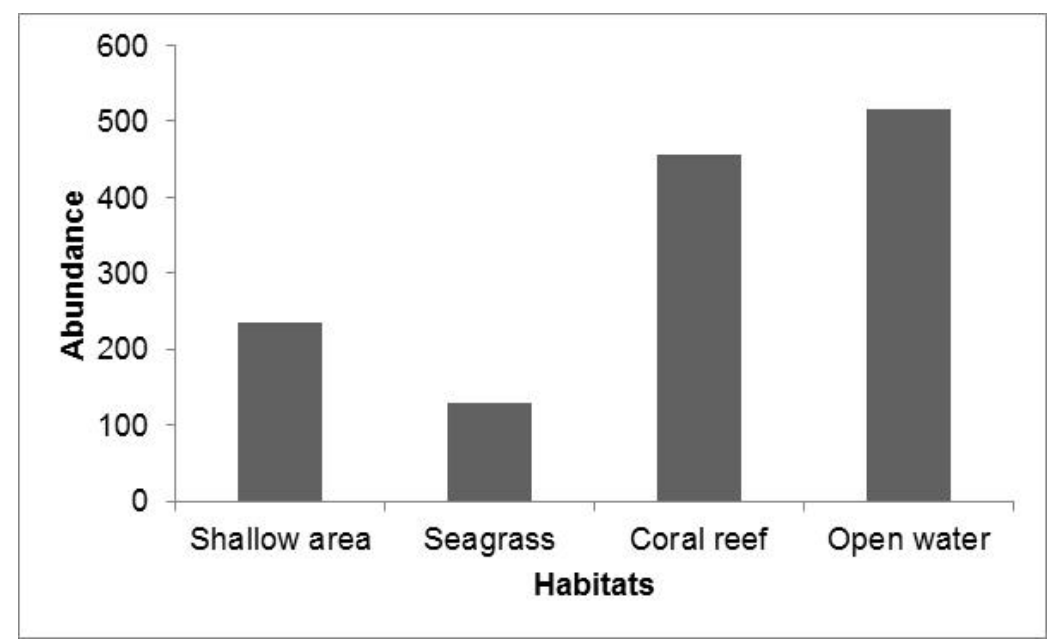

Fig. 3: Abundance of fish larvae (number of larvae/1000 $\mathrm{m}^{3}$ ) in all habitats

The abundance of fish larvae was high in late spring and summer (May-July) with the highest value in May $\left(350\right.$ individuals $\left./ 1000 \mathrm{~m}^{3}\right)$, followed by June $(305$ larvae $\left./ 1000 \mathrm{~m}^{3}\right)$ and July $\left(170 / 1000 \mathrm{~m}^{3}\right)$, whereas the lowest abundance was recorded in September $\left(11\right.$ individuals $/ 1000 \mathrm{~m}^{3}$ ) (Fig. 4). The Analysis of variance (one way ANOVA) showed that there was a significant difference between months $\left(X^{2}=0.723\right.$, $\mathrm{P}<0.05)$.

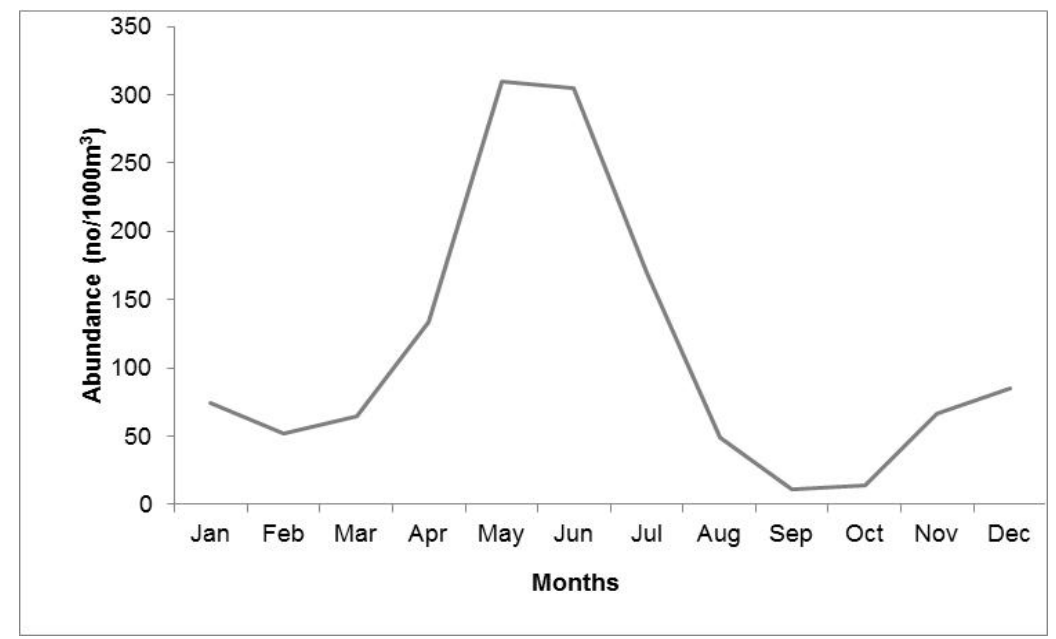

\section{Larval diversity}

Fig. 4: Monthly variation in larval fish abundance

Throughout the whole period of study, larvae of 57 taxa 40 families belonging to 13 orders of fish were identified. Larvae of 32 taxa forming approximately $23 \%$ of all taxa collected were taken in June recording the highest number of taxa followed by July and May (22 taxa and 21 taxa, respectively). The lowest number of taxa was recorded in September where 5 taxa were taken (Fig. 5). Seagrass areas, shallow lagoons, coral reef areas and open water areas, had 19, 31, 37, and 39 species, respectively (Fig. 6). 


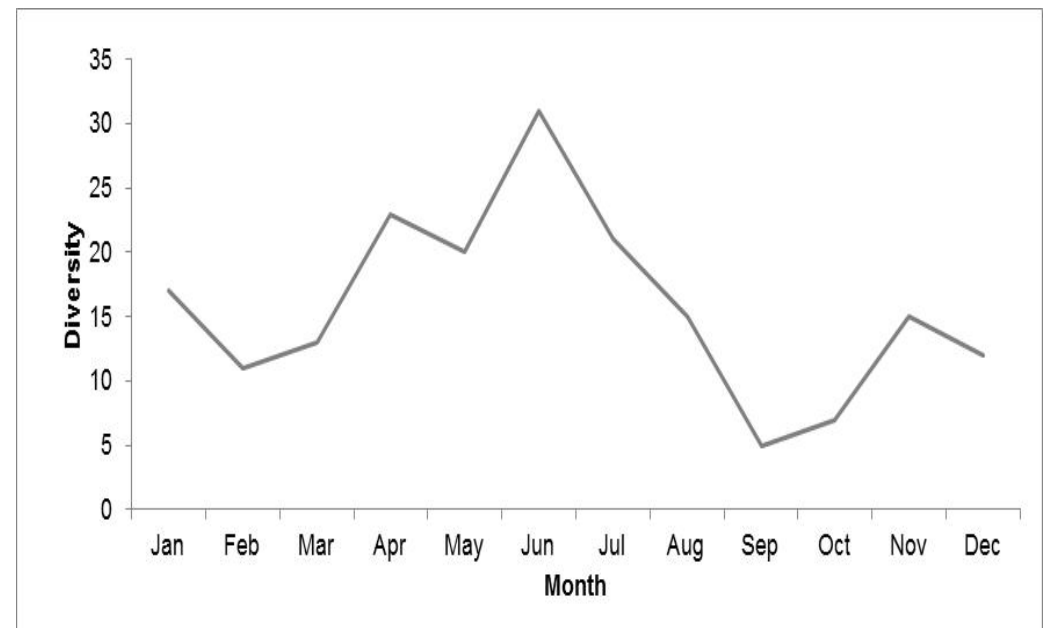

Fig. 5: Monthly variation in larval fish diversity

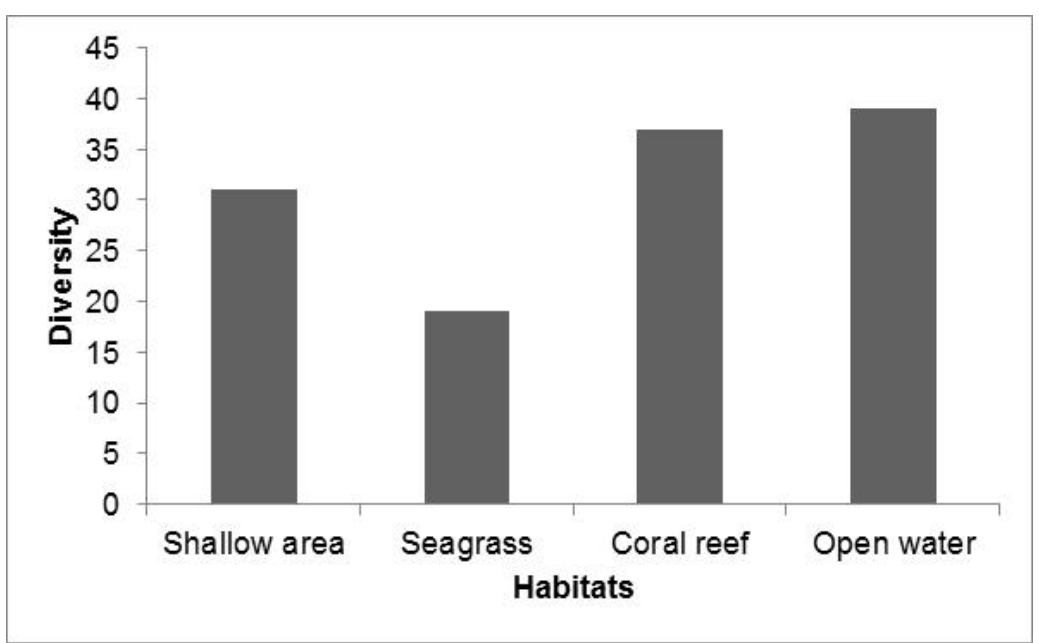

Fig. 6: Spatial variation in larval fish diversity

\section{Species composition}

In the present study ten families represent about $82.3 \%$ of all larvae collected. Larvae of families Mullidae and Clupeidae dominated the collection with 489 larvae forming $43.2 \%$, and 226 larvae (20.2\% of all collected larvae) respectively. Larvae of family Gerreidae was abundant with a percentage of $11.4 \%$. Tripterygiidae, Phosichthyidae were common with a percentage of $8.2 \%$ and $5.4 \%$ respectively (Fig. 7). Trichodontidae and Scombridae were represented by one larva.

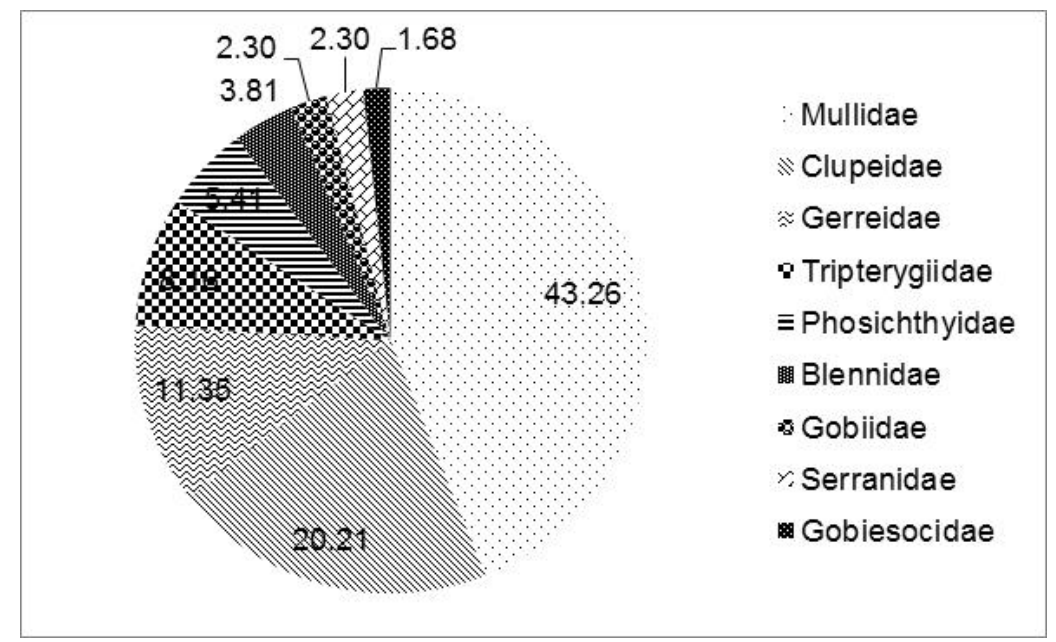

Fig. 7: Percentage contribution of the most abundant 10 taxa of fish larvae in all habitats 
Of the 13 fish orders recorded in the present study, the most diverse order was the Perciformes with 23 families and 34 taxa. The family with the highest number of taxa was Blennidae with 6 species. Spratelloides delicatulus was the most frequently recorded species where it was collected all over the year $(16.9 \%$ of all larvae collected). The most abundant 10 taxa, Mulloides flavolineatus (Mullidae), Spratelloides delicatulus (Clupeidae), Gerres oyena (Gerreidae), Tripterygiidae, Vinciguerria mabahiss, (Phosichthyidae), Omobranchus puctatus, (Blenniidae), Gobiidae, Serranidae, Gobiesocidae, and Labridae formed 82.3\%of all larvae. Mulloides flavolineatus was the most dominant contributing about $36.5 \%$ of all taxa with a total abundance of 489 larvae $/ 1000 \mathrm{~m}^{3}$ followed by Spratelloides delicatulus and Gerres oyena that constituted $16.9 \%$ and $9.6 \%$ respectively (Fig. 7). Larvae of families Trichodontidae, and Scombridae had the lowest abundance with one larva each (Table 1).

Table 1: Frequency, percentage, and cumulative percentage of fish larvae at different months.

\begin{tabular}{|c|c|c|c|c|c|c|c|c|c|c|c|c|c|c|c|c|c|c|c|}
\hline Species & Jan & Feb & Mar & Apr & May & Jun & Jul & Aug & Sep & Oct & Nov & Dec & SUM & AVE & STD & count & $\%$ & cum $\%$ & fre \\
\hline Mulloides flavolineatus & & & 3 & 4 & 217 & 168 & 80 & 12 & & & 3 & 1 & 488 & 61 & 86.29 & 8 & 36.5 & 36.5 & 66.7 \\
\hline Spratelloides delicatulus & 16 & 14 & 20 & 18 & 31 & 37 & 35 & 11 & 4 & 2 & 12 & 26 & 226 & 18.8 & 11.42 & 12 & 16.9 & 53.4 & 100.0 \\
\hline Gerres oyena & 2 & & 3 & 27 & 6 & 24 & 17 & 14 & 5 & 4 & 26 & & 128 & 12.8 & 10.10 & 10 & 9.6 & 63.0 & 83.3 \\
\hline Tripterygiidae & 27 & 8 & 4 & 16 & 6 & 1 & 4 & & & & 5 & 21 & 92 & 10.2 & 8.97 & 9 & 6.9 & 69.9 & 75.0 \\
\hline Vinciguerria mabahiss & 4 & 8 & 16 & 2 & 7 & 1 & 4 & 1 & & & 4 & 16 & 63 & 6.3 & 5.60 & 10 & 4.7 & 74.6 & 83.3 \\
\hline Gobiidae & & & 9 & 1 & 6 & 5 & 2 & & & & 1 & 2 & 26 & 3.71 & 3.04 & 7 & 1.9 & 76.6 & 58.3 \\
\hline Omobranchus puctatus & & 1 & & 3 & 7 & 6 & 3 & 1 & & 1 & 1 & & 23 & 2.88 & 2.42 & 8 & 1.7 & 78.3 & 66.7 \\
\hline Gobiesocidae & 2 & 7 & 3 & & 2 & & 1 & & & & & 4 & 19 & 3.17 & 2.14 & 6 & 1.4 & 79.7 & 50.0 \\
\hline Labridae & & & & & 1 & 15 & 1 & & & & & & 17 & 5.67 & 8.08 & 3 & 1.3 & 81.0 & 25.0 \\
\hline Serranidae & 4 & 1 & 1 & 1 & 1 & 4 & 1 & 1 & & & 2 & 1 & 17 & 1.7 & 1.25 & 10 & 1.3 & 82.3 & 83.3 \\
\hline Carangidae & & 2 & & & 4 & 2 & 3 & & & 1 & 2 & 1 & 15 & 2.14 & 1.07 & 7 & 1.1 & 83.4 & 58.3 \\
\hline Haemulidae & 2 & 2 & & 9 & 1 & & & 1 & & & & & 15 & 3 & 3.39 & 5 & 1.1 & 84.5 & 41.7 \\
\hline Syngnathidae & 1 & & & 2 & & 4 & 2 & 1 & & 4 & & & 14 & 2.33 & 1.37 & 6 & 1.0 & 85.6 & 50.0 \\
\hline Scorpaenidae & & & & & 4 & 2 & 1 & & 1 & & 4 & & 12 & 2.4 & 1.52 & 5 & 0.9 & 86.5 & 41.7 \\
\hline Atherinomorus lacunosus & & & & 7 & & 2 & & & 1 & & & 1 & 11 & 2.75 & 2.87 & 4 & 0.8 & 87.3 & 33.3 \\
\hline Tetraodontidae & 1 & & & 5 & 1 & 1 & 3 & & & & & & 11 & 2.2 & 1.79 & 5 & 0.8 & 88.1 & 41.7 \\
\hline Blenniidae 2 & & & & 7 & & & & 1 & & & & & 8 & 4 & 4.24 & 2 & 0.6 & 88.7 & 16.7 \\
\hline Petroscirtes mitratus & & & 1 & 3 & 1 & & 1 & 2 & & & & & 8 & 1.6 & 0.89 & 5 & 0.6 & 89.3 & 41.7 \\
\hline Sphyraena barracuda & & & & & & 8 & & & & & & & 8 & 8 & 0.00 & 1 & 0.6 & 89.9 & 8.3 \\
\hline Caranx sp & 2 & & & & 2 & 1 & 1 & & & & & & 6 & 1.5 & 0.58 & 4 & 0.4 & 90.3 & 33.3 \\
\hline Priacanthus hamrur & & & & & 1 & 2 & 1 & & & & & & 4 & 1.33 & 0.58 & 3 & 0.3 & 90.6 & 25.0 \\
\hline Pseudoanthias squamipinnis & 2 & & & 1 & & & & & & & 1 & & 4 & 1.33 & 0.58 & 3 & 0.3 & 90.9 & 25.0 \\
\hline Serranidae Serraninae & & & & 4 & & & & & & & & & 4 & 4 & 0.00 & 1 & 0.3 & 91.2 & 8.3 \\
\hline Abudefduf saxatilis & & & & & 2 & 1 & & & & & & & 3 & 1.5 & 0.71 & 2 & 0.2 & 91.5 & 16.7 \\
\hline Atherinidae & & & & 2 & & 1 & & & & & & & 3 & 1.5 & 0.71 & 2 & 0.2 & 91.7 & 16.7 \\
\hline Lutjanidae & & & 2 & & & 1 & & & & & & & 3 & 1.5 & 0.71 & 2 & 0.2 & 91.9 & 16.7 \\
\hline Benthosema pterotum & & 3 & & & & & & & & & & & 3 & 3 & 0.00 & 1 & 0.2 & 92.1 & 8.3 \\
\hline Pomacentridae & & & & & & 2 & 1 & & & & & & 3 & 1.5 & 0.71 & 2 & 0.2 & 92.4 & 16.7 \\
\hline Astronesthidae & 2 & & & & & & & & & & & & 2 & 2 & 0.00 & 1 & 0.1 & 92.5 & 8.3 \\
\hline Hypoatherina temminckii & & & & 1 & & 1 & & & & & & & 2 & 1 & 0.00 & 2 & 0.1 & 92.7 & 16.7 \\
\hline Atherinomorus forskalii & & & & & & & & & & 2 & & & 2 & 2 & 0.00 & 1 & 0.1 & 92.8 & 8.3 \\
\hline Blenniidae & & & 1 & & & 1 & & & & & & & 2 & 1 & 0.00 & 2 & 0.1 & 93.0 & 16.7 \\
\hline Callionymidae & & 1 & & & & & 1 & & & & & & 2 & 1 & 0.00 & 2 & 0.1 & 93.1 & 16.7 \\
\hline Holocentridae & & & & & & 2 & & & & & & & 2 & 2 & 0.00 & 1 & 0.1 & 93.3 & 8.3 \\
\hline Scaridae & & & & 1 & & 1 & & & & & & & 2 & 1 & 0.00 & 2 & 0.1 & 93.4 & 16.7 \\
\hline Balistidae & & & & & & 2 & & & & & & & 2 & 2 & 0.00 & 1 & 0.1 & 93.6 & 8.3 \\
\hline Apogonidae & & & & 1 & & & & & & & & & 1 & 1 & 0.00 & 1 & 0.1 & 93.6 & 8.3 \\
\hline Escenius sp & & & 1 & & & & & & & & & & 1 & 1 & 0.00 & 1 & 0.1 & 93.7 & 8.3 \\
\hline Meiacanthus nigrolineatus & & & & & & 1 & & & & & & & 1 & 1 & 0.00 & 1 & 0.1 & 93.8 & 8.3 \\
\hline Cirritidae & & & & & & & & & & & 1 & & 1 & 1 & 0.00 & 1 & 0.1 & 93.9 & 8.3 \\
\hline Eleotridae & & & & 1 & & & & & & & & & 1 & 1 & 0.00 & 1 & 0.1 & 93.9 & 8.3 \\
\hline Bothidae & 1 & & & & & & & & & & & & 1 & 1 & 0.00 & 1 & 0.1 & 94.0 & 8.3 \\
\hline Exocoetidae & 1 & & & & & & & & & & & & 1 & 1 & 0.00 & 1 & 0.1 & 94.1 & 8.3 \\
\hline Microdismidae & & & & & & & & & & & & 1 & 1 & 1 & 0.00 & 1 & 0.1 & 94.2 & 8.3 \\
\hline Mullidae 2 & & & & & & 1 & & & & & & & 1 & 1 & 0.00 & 1 & 0.1 & 94.2 & 8.3 \\
\hline Nemipteridae & 1 & & & & & & & & & & & & 1 & 1 & 0.00 & 1 & 0.1 & 94.3 & 8.3 \\
\hline Pegasidae & & & & & & & & 1 & & & & & 1 & 1 & 0.00 & 1 & 0.1 & 94.4 & 8.3 \\
\hline Pempheris vanicolensis & & & & 1 & & & & & & & & & 1 & 1 & 0.00 & 1 & 0.1 & 94.5 & 8.3 \\
\hline Pomacanthidae & & & & & & & & & & & 1 & & 1 & 1 & 0.00 & 1 & 0.1 & 94.5 & 8.3 \\
\hline Pomacanthus sp & & & & & & 1 & & & & & & & 1 & 1 & 0.00 & 1 & 0.1 & 94.6 & 8.3 \\
\hline Samaridae & & & & & & & & 1 & & & & & 1 & 1 & 0.00 & 1 & 0.1 & 94.7 & 8.3 \\
\hline Scomber japonicus & & & & & & & & 1 & & & & & 1 & 1 & 0.00 & 1 & 0.1 & 94.8 & 8.3 \\
\hline Scombridae & & & & & & 1 & & & & & & & 1 & 1 & 0.00 & 1 & 0.1 & 94.8 & 8.3 \\
\hline Epinephelus sp. & & & & & 1 & & & & & & & & 1 & 1 & 0.00 & 1 & 0.1 & 94.9 & 8.3 \\
\hline Trichodontidae & 1 & & & & & & & & & & & & 1 & 1 & 0.00 & 1 & 0.1 & 95.0 & 8.3 \\
\hline Hyporhamphus gamberur & & & & & & & 1 & & & & & & 1 & 1 & 0.00 & 1 & 0.1 & 95.1 & 8.3 \\
\hline UK & 5 & 5 & 1 & 17 & 9 & 6 & 7 & 1 & & & 4 & 11 & 66 & 6.6 & 4.81 & 10 & 4.9 & 100.0 & 83.3 \\
\hline count & 17 & 11 & 13 & 23 & 20 & 31 & 21 & 14 & 4 & 6 & 14 & 11 & & & & & & & \\
\hline Sum & 74 & 52 & 65 & 134 & 310 & 305 & 170 & 49 & 11 & 14 & 67 & 85 & 1336 & & & & & & \\
\hline
\end{tabular}


Regarding the spatial distribution of diversity index, the highest species richness was 6.08 in the open water area, whereas the lowest species richness (3.7) was recorded in the seagrass area (Fig. 8). The species evenness fluctuated between the lowest value of 0.56 recorded in the open water area to the highest of 0.69 in the coral reef area (Fig. 9).

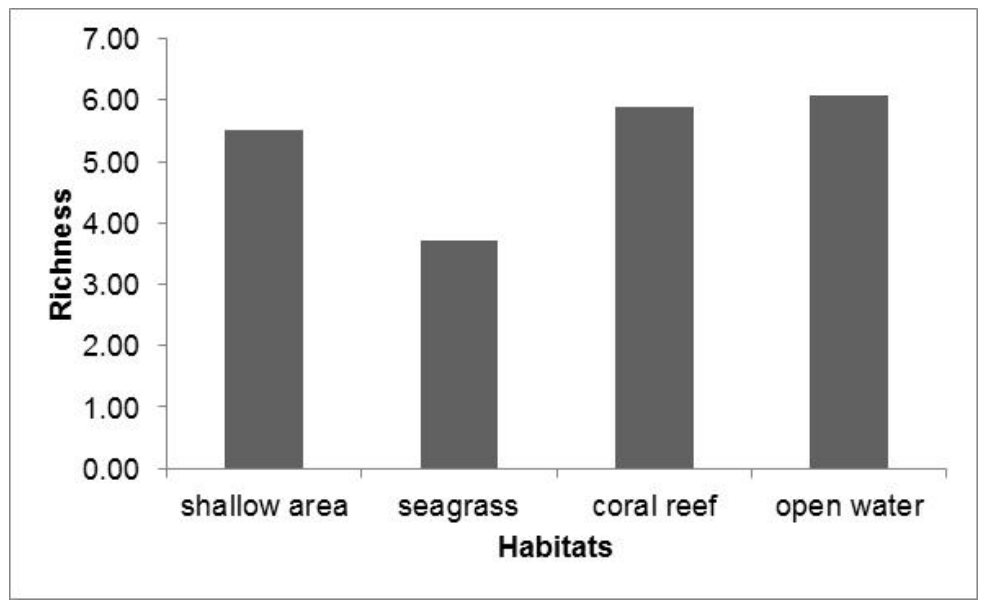

Fig. 8: Spatial variations in richness of diversity in habitats

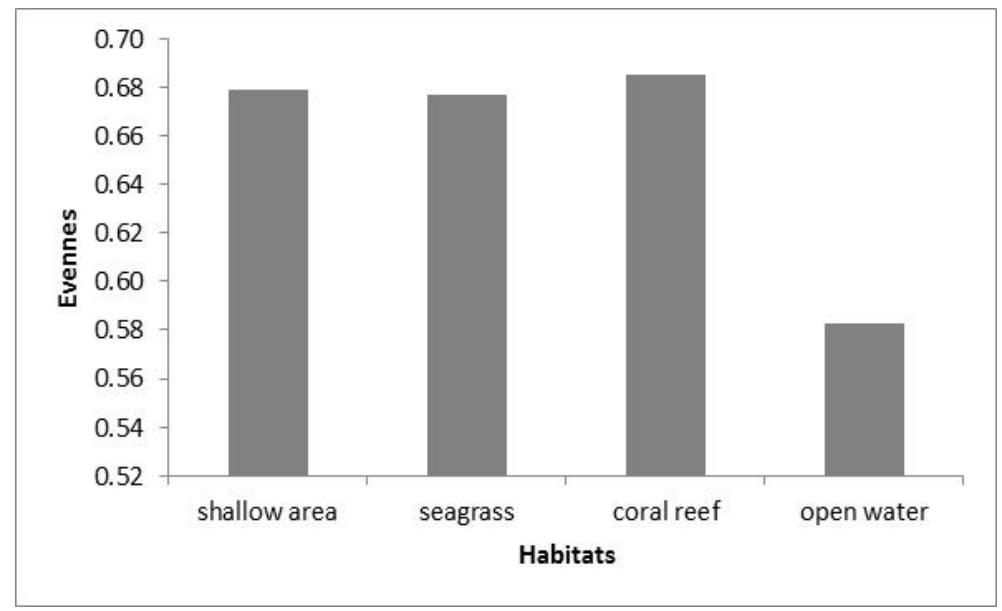

Fig. 9: Spatial variations in evenness of diversity in habitats

The highest species diversity index was 2.48 recorded in the coral reef area, where the lowest species diversity index was in the seagrass area with 1.99 (Fig. 10).

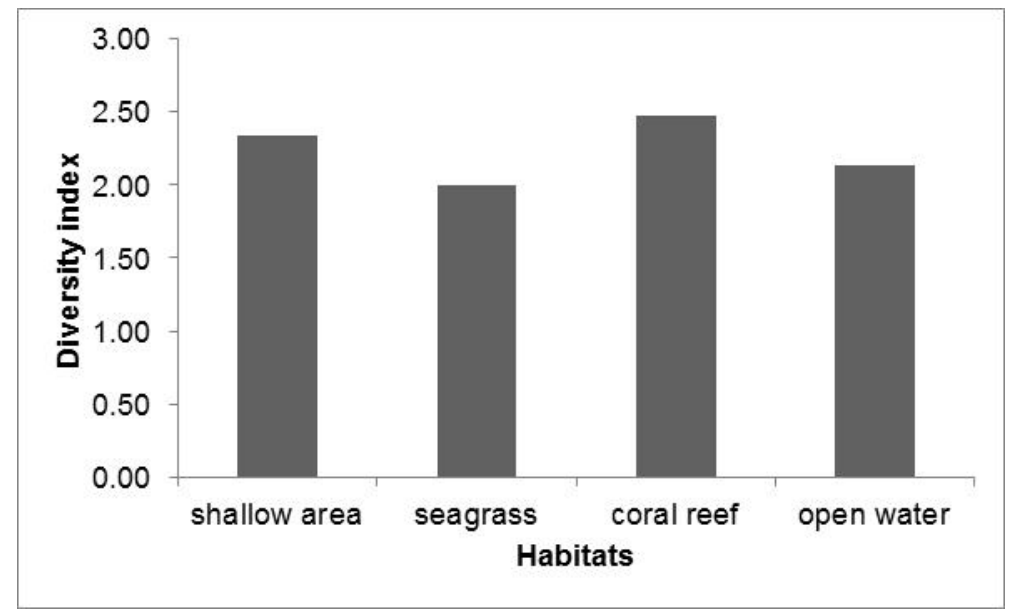

Fig. 10: Spatial variations in evenness of Diversity index in habitats in habitats 
The analysis of similarity index showed that three habitats, open water, coral reef and shallow lagoons are closely similar with a similarity of $65 \%$. Seagrass was slightly different from the other sites (Fig. 11).

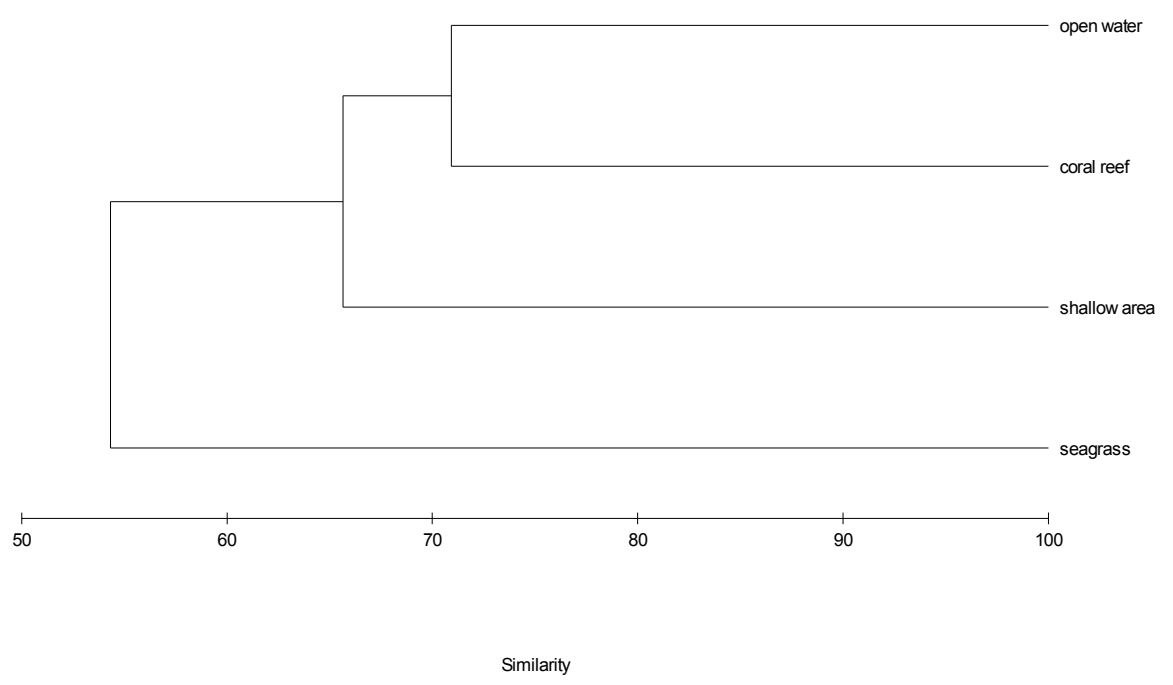

Fig. 11: Similarity cluster of between the different habitats in the study area

\section{Similarity index of species in habitats:}

The similarity index for species in habitats (Figure, 12) showed that it could be divided the species in habitats into five clusters of which the first cluster was the biggest with 22 taxa and a similarity of $48 \%$ inside this cluster Carangidae and Serranidae had a similarity of $95 \%$, Tetraodontidae and Syngnathidae had a similarity of $94 \%$ and Caranx sp. and Petroscirtes mitratus had a similarity of $92 \%$. The second cluster contains 11 taxa with a similarity of $60 \%$, inside this cluster Hypoatherina temminckii, Holocentridae and Scaridae had a similarity of $100 \%$. Bothidae, Exocoetidae, Microdismidae, Trichodontidae, and Meiacanthus nigrolineatus had a similarity of $100 \%$. The third cluster contains contains 11 taxa, inside this cluster Balistidae, Blenniidae, and Atherinomorus forskalii have a similarity of $100 \%$.

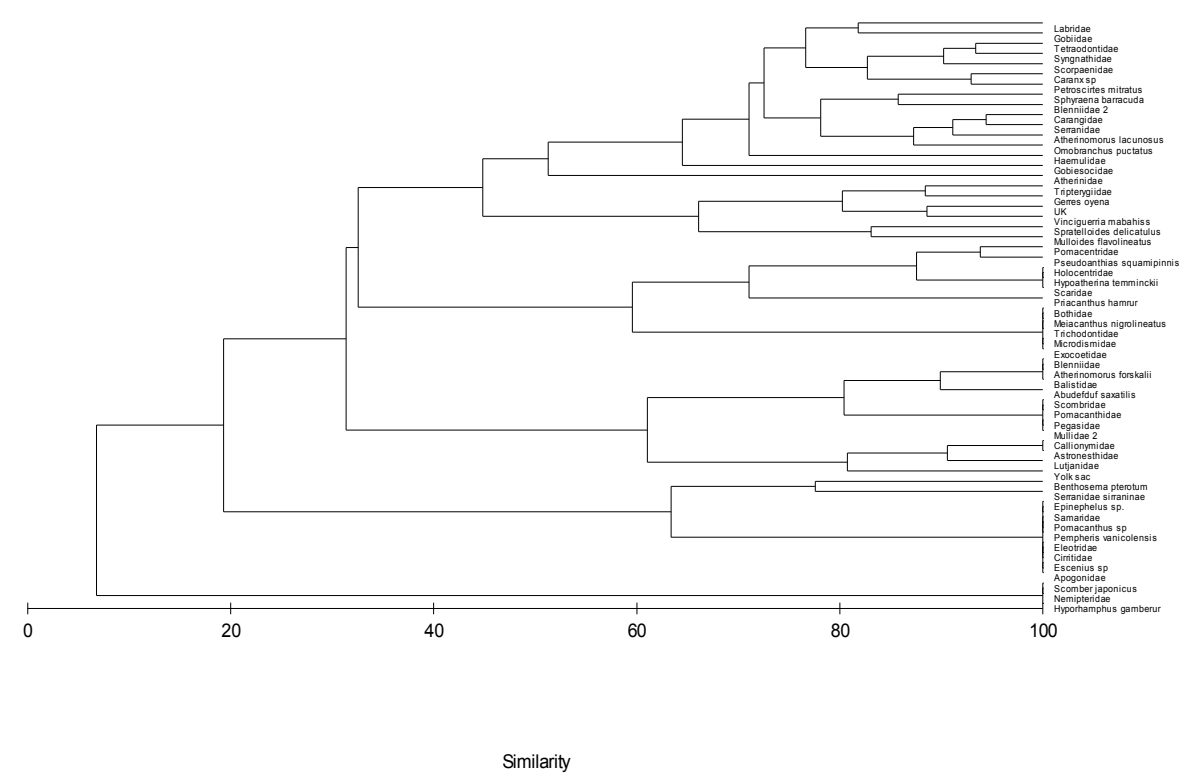

Fig. 12: Similarity cluster of between the species in the study area 
The fourth cluster contains ten taxa, inside this cluster Apogonidae, Escenius sp, Cirritidae, Eleotridae, Samaridae, Epinephlus sp., Pomacanthus sp., Pempheris vanicolensis with a similarity of $100 \%$, because they were collected only in coral reef areas and represented by the one individual. The fifth cluster contains three taxa inside this cluster Nemipteridae, Scomber japonicas, and Hyporhamphus gamberur with a similarity of $100 \%$, because they were collected only in seagrass areas and represented by the one individual.

Analysis of variance (One Way ANOVA) showed that there was a highly significant difference between abundance and months $(\mathrm{F}=7.3, \mathrm{P}<0.05)$ and habitat $(\mathrm{F}=5.08, \mathrm{P}<0.05)$. the diversity of fish larvae was highly significantly different in habitat $(\mathrm{F}=51, \mathrm{P}<0.05)$ but not in months $(\mathrm{F}=0.0, \mathrm{P}>0.05)$. The interaction between months and habitat was significantly different for fish larval abundance but not for diversity as indicated by Two Way ANOVA.

Larvae of commercial species formed $69 \%$ of the total larvae collected with 926 larvae belonging to 21 species that formed $40 \%$ of all species. They have the highest abundance in the open water area with 369 larvae forming $77 \%$ of all larvae in this habitat, whereas the lowest abundance was recorded in the seagrass area with 96 larvae forming $74 \%$ of all larvae. The highest number of commercial species was 14 species recorded in the open water area, whereas the lowest number was 9 species recorded in the seagrass area.

Larvae of coral reef fishes dominated the collection forming about $71 \%$ of all collected larvae. A total of 44 species of coral reef fishes were represented by larvae in the area forming $81 \%$ of the total number of species collected. Coral reef fish larvae formed about $80 \%$ of total larvae outside the bay and $70 \%$ of the total larvae inside the bay. It could be noticed that larvae of pelagic and mesopelagic fishes were more abundant inside the bay than outside the bay. They formed $30 \%$ of the total larvae taken from the bay compared to $20 \%$ of the larvae outside the bay.

\section{Size composition}

The size of the collected larvae fluctuated between $1.2 \mathrm{~mm}$ and $28 \mathrm{~mm}$. Scorpaenid larvae collected in September from the coral reef area was determined as the smallest with a total length of $1.2 \mathrm{~mm}$, whereas; the largest larva was carangid with a total length of $28 \mathrm{~mm}$ taken from the shallow area in November. In general, the preflexion larvae formed $85 \%$ of the collected larvae with 1135 larvae, whereas, the postflexion larvae formed 15\% with 201 larvae (Fig. 13).

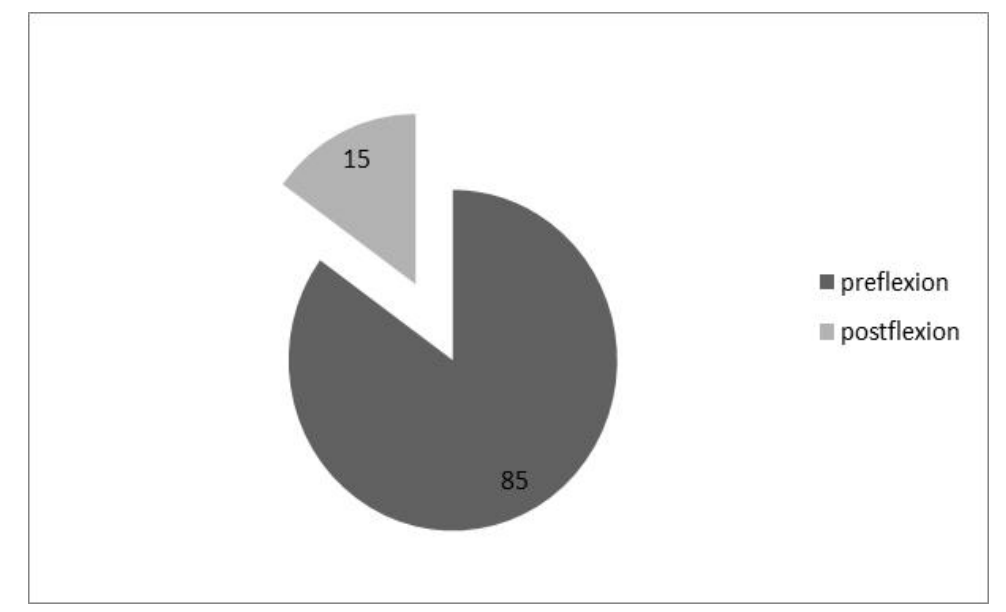

Fig 13: The percentage of preflexion and postflexion larvae 
Fish larvae inside Mabahiss bay habitats:

Seagrass area

A total of 129 larvae were collected from the seagrass area representing 19 taxa. The most abundant 5 taxa in this habitat formed $85.3 \%$ of the collected larvae. This habitat was dominated by Mulloides flavolineatus and Spratelloides delicatulus with 35 larvae forming about $27.1 \%$ of all larvae recorded for each Gerres oyena was abundant with 20 larvae that formed $15.5 \%$ of all larvae.

A total of 10 taxa were rare in the collection with only one larva. The size of larvae at this station fluctuated between $2.1 \mathrm{~mm}$ to $17 \mathrm{~mm}$. Spratelloides delicatulus was recorded as the largest larva with a total length of $17 \mathrm{~mm}$ and collected in August. Gobiid and Tripterygiid larvae had a small size of $2.1 \mathrm{~mm}$ and collected during July, and April respectively.

The collection of larvae in seagrass was dominated by the small and preflexion larvae where 101 larvae forming $78.3 \%$ of all larvae were collected (Fig. 14). Larvae of commercial species in the seagrass area formed $74 \%$ of the total larvae collected with 96 larvae belonging to 6 species that formed $47 \%$ of all species.

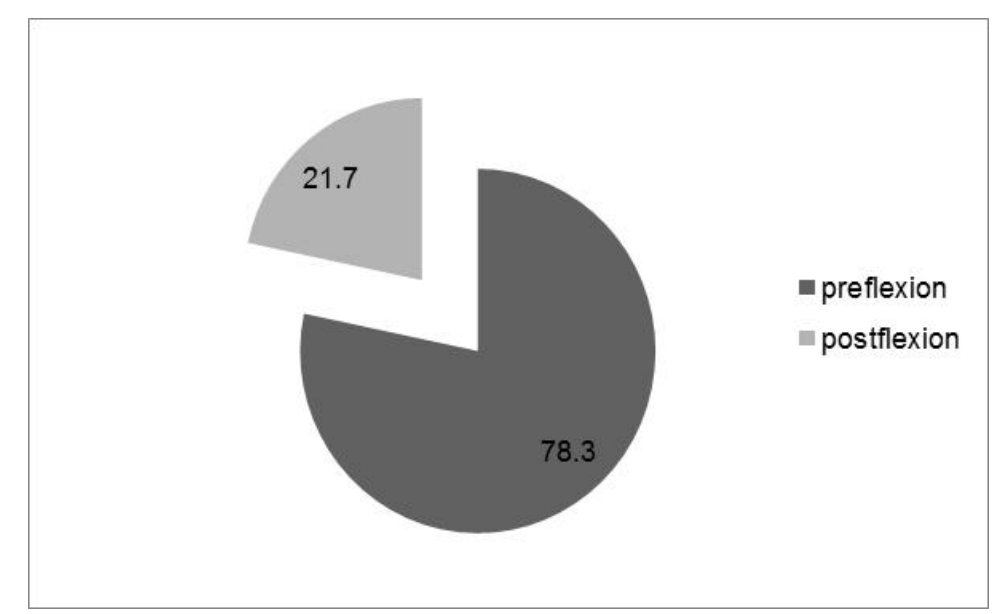

Fig. 14: The percentage of preflexion and postflexion larvae in the seagrass area

\section{Shallow lagoons}

Sampling the shallow lagoons resulted in recording of 234 larvae representing 31 taxa. The most abundant 5 taxa formed $75.6 \%$ of the collected taxa. The dominant species was Mulloides flavolineatus with 77 larvae forming about $32.9 \%$ of all larvae recorded at this habitat. Spratelloides delicatulus was abundant with 46 larvae that formed $19.7 \%$ of all larvae. Gerres oyena and Tripterygiidae were common with 19 larvae forming about $8.1 \%$ for each.

About half of the species ( $45 \%$ of the species) recorded in this habitat were represented by one larvae. The size of larvae at shallow lagoonsranged between $1.2 \mathrm{~mm}$ to $28 \mathrm{~mm}$. The largest larvae was that of Carangid collected in July with $28 \mathrm{~mm}$. whereas the smallest larva was Scorpaenid larva with a total length of $1.2 \mathrm{~mm}$ taken in September. Larvae were dominated by the small preflexion larvae that formed about $82 \%$ of all larvae (Fig. 15).

Larvae of commercial species in the shallow lagoons formed $66 \%$ of the total larvae collected with 155 larvae belonging to 12 species that formed $39 \%$ of all species.

\section{Coral reef area}

Samples collected from the coral reefs included 456 larvae representing 37 taxa. The most abundant 5 taxa formed $72.1 \%$ of the collected taxa. This habitat was 
dominated by Mulloides flavolineatus with 123 larvae forming about $27 \%$ of all larvae recorded. Spratelloides delicatulus was the most abundant species with 88 larvae that formed $19.3 \%$ of all larvae. Gerres oyena and Vinciguerria mabahiss were common in this habitat with 40 and 32 larvae, forming $8.8 \%$, and $7 \%$ of all larvae recorded, respectively.

The blennid Escenius larva taken in March had the largest size with a total length of $19.5 \mathrm{~mm}$. The smallest larva was Serranid larva with a total length of 1.3 $\mathrm{mm}$ and collected in April. The preflexion larvae formed more than $90 \%$ of the total larvae with 413 larvae (Fig. 16).

Larvae of commercial species in the coral reef area formed $61 \%$ of the total larvae collected with 279 larvae belonging to 12 species that formed $32 \%$ of all species.

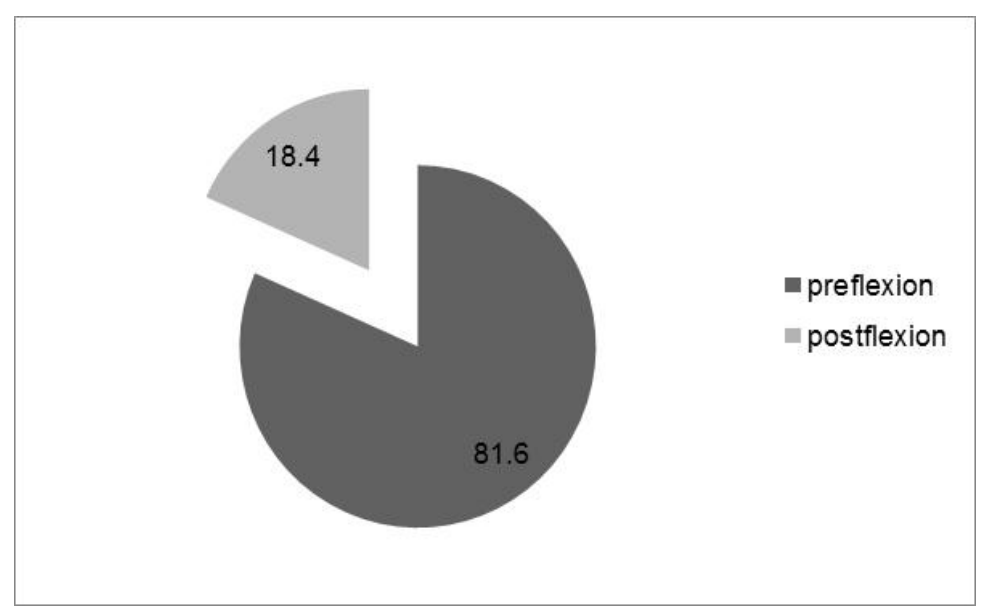

Fig. 15: The percentage of preflexion and postflexion larvae in the seagrass area

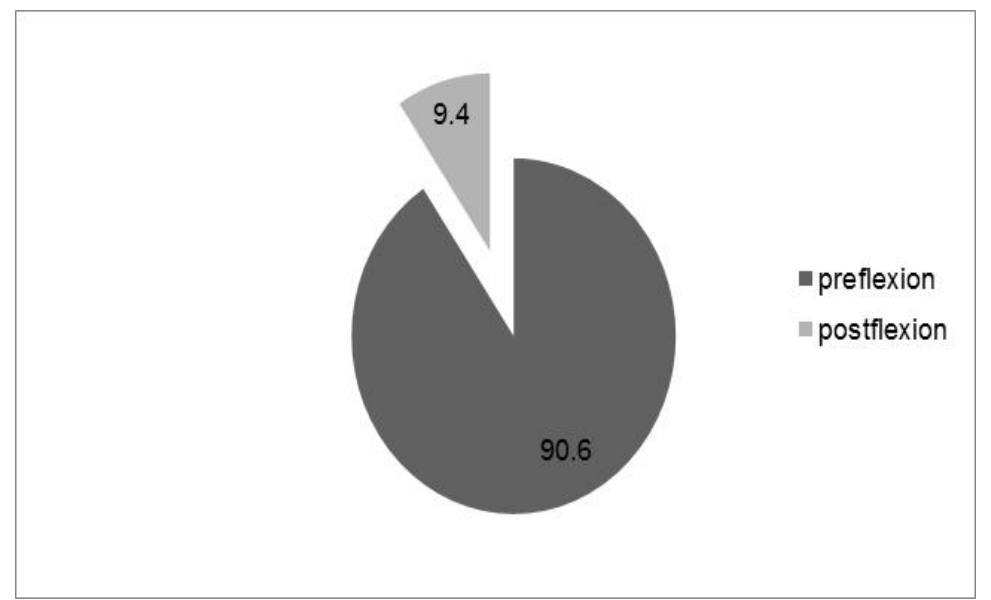

Fig. 16: The percentage of preflexion and postflexion larvae in the coral reef area

\section{Fish larvae outside the bay}

\section{Open water area}

This habitat was characterized by the highest abundance and diversity of fish larvae with 517 larvae representing 39 taxa. The most abundant 5 taxa constituted $74.9 \%$ of the collected larvae. Larvae of Mulloides flavolineatus dominated this habitat with 253 larvae forming about 48.9\% of all larvae (Fig. 17).

Larvae of 12 taxa were rare with general abundance of only one larva constituting $0.2 \%$ for each. The size of larvae at this station fluctuated between 1.5 $\mathrm{mm}$ to $23 \mathrm{~mm}$. A $23 \mathrm{~mm}$ barracuda larva (Sphyraena barracuda) collected in March 
was recorded as the largest larva, whereas, larvae of Mulloides flavolineatus, recorded the smallest size of $1.5 \mathrm{~mm}$ collected in July.

The majority of larvae taken from the open water were small and preflexion where 430 larvae $(83.2 \%$ of the larvae), were collected compared to 87 postflexion larvae forming $16.8 \%$ (Fig. 17).

Larvae of commercial species in the open water area forming $77 \%$ of the total larvae with 396 larvae belonging to 14 species that formed $36 \%$ of all species.

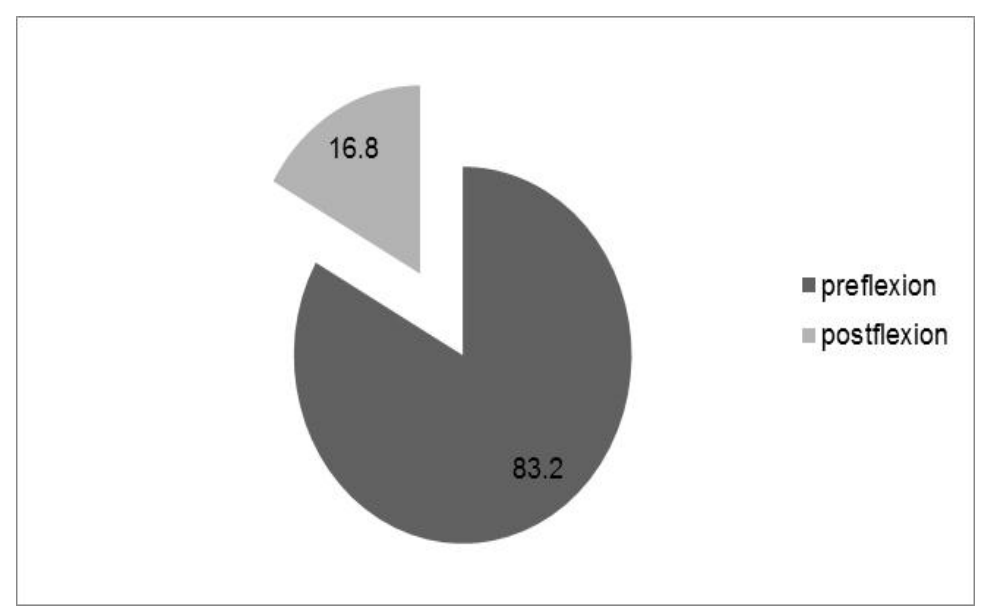

Fig. 17: The percentage of preflexion and postflexion larvae in the coral reef area

\section{DISCUSSION}

Little is known about where most fish species spend their pelagic period. Larvae of many species have been collected near the shore and others have been collected away from the shore. Some studies have been carried out on the species composition of larval fish inshore and offshore (Clark, 1991; Leis, 1986a, 1991a). The distribution patterns obtained were independent of the spawning mode of species (Borges et al., 2007, Abu El-Regal, 2008b). The interest in fish larval communities has increased noticeably during the last two decades as a tool to provide insights into the ecology and dynamics of marine fish larvae (Moser \& Smith, 1993, Abu El-Regal, 2008).

Despite their importance for fisheries management, very few studies are available about the Red Sea reef fish larvae. As it is needed to estimate the size of a spawning stock and to determine the spawning seasons and spawning grounds of the commercial fishes, information is necessarily and urgently needed as a tool to manage the Red Sea fisheries and its coral reefs (Abu El-Regal, 2008). The present study has complemented the previous studies on the larvae of the coral reef fishes in the Red Sea: southern Red Sea (Nellen, 1973), Sharm El-Sheikh (Abu El-Regal, 1999), Aqaba (Faroukh, 2001) and Hurghada (Abu El-Regal, 2008, Abu El-Regal et al., 2008a). All of these studies aimed to identify the larval fishes in the studied area and to give some notes about their seasonal and regional distribution (El-Sherbiny, 1997; Cuschnir, 1991; Abu El-Regal, 1999, 2009; Faroukh, 2001).

Reports on the larval fishes in the northern Red Sea revealed that the abundance of larvae of coral reef fishes is generally low (El-Sherbiny, 1997; Cuschnir, 1991; Abu El-Regal, 1999; Faroukh, 2001). Abu El-Regal et al. (2008b) studied the influence of ecological guilds of the adult stages on the dispersal of their larval stages and found that the distribution is affected by the spawning mode but not the habitat of the adult or the depth at which the adult lives. Physical parameters such as 
temperature in the Red Sea in general do not vary greatly. So, the spatial distribution is not correlated to the temperature. (Abu El-Regal, 2008).

Borges et al. (2007) found that diversity and total larval abundance decreased significantly with increasing distance from shore in Portugal waters.

The abundance and distribution of larvae may be strongly related to the habitat type or spawning ground of the adult. These correspond to areas that favor the subsequent coupling between spawned cohorts and the presence of food (Cushing, 1990). The distribution of fish larvae can be determined by spawning behaviour of their adults, hydrography and topography of the reef, duration of larval period, behaviour, growth and mortality of the larvae (Cushing, 1990; Leis, 1991a, Montgomery et al., 2001; Leis et al., 2006).

The larval fish assemblages in coastal tropical waters are a result of spawning activities of reef fish, and open water fish often dominated by mesopelagic fishes (Ahlstrom, 1971; 1972; Leis \& Goldman, 1987). Larval mesopelagic fishes are represented in the present study by five species, $V$. mabahiss and B. pterotum, Astronesthes martensii, Scomber japonicus, and an identified species of scombridae. They formed 5.2\% of all collected larvae where 70 larvae were recorded of which $V$. mabahiss formed 90\% (63 larvae). V. mabahiss accounted for about $18 \%$ of larvae at Sharm El-Sheikh (Abu El-Regal 1999), 10.7\% in Hurghada (Abu El-Regal 2008) compared to less than $4.7 \%$ of larvae collected in the present study. B. pterotum was rare in the present collection 3 larvae $/ 1000 \mathrm{~m}^{3}$ in the present study comparing with (Abu El-Regal 2008) 3 larvae/1000 $\mathrm{m}^{3}$ in Hurghada.

The current study has shown that there were two assemblages of larvae with different distributions; inside and outside the bay assemblages. Both assemblages were dominated by larvae of reef fishes. However, larvae of reef fishes were abundant outside the bay constituting about $80 \%$ of all larvae. The inside assemblages had more larvae of pelagic species than those outside the bay. The high densities of pelagic larvae inside the bay could be attributed to the high concentration of clupeid Spratelloides delicatulus. Futheromre, the inside assemblage was composed mainly of larvae of demersal spawners while the outside assemblage was composed mainly of larvae of pelagic spawners. This result is in a full agreement with the findings of Leis (1982); Smith et al. (1987), Clarck (1991), Suthers \& Frank (1991), Leis \& McCormic (2002) and Paris and Cowen (2004). Brogan (1994) stated that larvae from demersal spawners can be used to measure the larval retention. Leis (1982) showed that, the dominance of larvae of demersal species near shore was due to a few species.

In the present study, the high abundance of larvae of demersal spawners was due to the high larval density of families with demersal eggs such as Clupeidae and Tripterygiidae. Larvae of Spratelloides delicatulus (Clupeidae) were very highly abundant, with a total abundance of 226 larvae $/ 1000 \mathrm{~m}^{3}$ and while Tripterygiid larvae ware 92 larvae $/ 1000 \mathrm{~m}^{3}$ respectively.

\section{Species composition:}

In general, larvae of 53 families of fish were recorded in the area of which 40 families were collected during the present study. This number of families was less than that recorded from the same area (Abu El-Regal, 2008) where 44 families were taken.

Larvae of families Muraenidae, Ophichthidae, Engraulidae, Synodontidae, Bythitidae, Belonidae, Mugilidae, Fistualridae, Sparidae, Acanthuridae, Siganidae, Ostraciidae, Diodontidae, and Soleidae are recorded from the area (Abu El-Regal, 2008) but missed in the during study. On the other hand larvae of families Astronesthidae, Gobiesocidae, Trichodontidae, Nemipteridae, Cirrhitidae, 
,Scombridae, Balastidae, Scorpaenidae, Pegasidae, and Samaridae are recorded during the presnet study but were not collected in 2008 (table 1.). This could be due to the wider geographical area covered by Abu El-Regal, 2008 that included Giftun islands. Four families Siganidae, Acanthuridae, Solidae, and Synodontidae absent from the present collection were collected only from El-Giftun island area which not surveyed in the present study.

This number of families was more than those collected from Aqaba (25) (Farouhk 2001) and Sharm El-Sheikh (32) (Abu El-Regal, 1999). Although more taxa were identified at Aqaba. Larvae of some families such as Pomacanthidae, Scaridae, Microdesmidae, and Gerreidae were collected from Hurghada but not from Aqaba and Sharm El-Sheikh. Of the most abundant families in Aqaba, Clupeidae, Pomacentridae, Apogonidae and Gobiidae, only clupeid larvae were abundant in the present collection. Differences in species composition and abundance of fish larvae between Sharm El-Sheikh and Hurghada collections were small because of the similar environmental conditions. Collection from Hurghada was made with small plankton nets and most larvae were small and preflexion stage compared to the larger larvae collected from Jordanian waters by Faroukh (2001) who used a light trap that captures larger larvae. Rarity or absence of larvae of some taxa may be due to the sampling gears.

Most of the larval fish taxa collected during the current study are commercially important. Mullidae (Goatfish), Clupeidae (Sardine), Lutjanidae (Snappers), Heamulidae (Sweetlips), Scaridae (Parrotfish), Carangidae (Jacks), Sphyraenidae (Barracuda), Gerreidae (Mojarras), and Serranidae (Groupers) whose larvae are common in the present collection are important constituents of the fishery in the Red Sea in general and Hurghada in particular.

Data about where and when larvae of these commercial fish could be very helpful in the determination of their spawning seasons and grounds and hence management of their fisheries of the Red Sea. However, the larvae of some important constituents of Egyptian fisheries were rare or even absent, perhaps reflecting the behaviour of the adults or larvae (Leis, 1991b; Montgomery et al., 2001). Larval sparids, lethrinids, and mugilids were absent in this study. There are a few reports of the larvalsparids, and mugilids from the area (Abu El-Regal, 2008) whereas lethrinid larvae were absent from all previous and current studies in the Red Sea. The absence of larvae of certain species may confirm that these fishes to migrate to areas more favourable for spawning (Johannes, 1978). Lethrinid fish migrates to Ras Mohamed protected area to spawn in summer as indicated by the fishing season known in the area from April to June (Personal communication).

\section{REFERENCES}

Abu El-Regal, M.A. (1999). Some biological and ecological studies on the larvae of coral reef fishes in Sharm El-Sheikh (Gulf of Aqaba-Red Sea). M.Sc. Thesis. Mar. Sci. Dept., Fac. Sci., Suez Canal Univ., 167 pp.

Abu El-Regal, M.A. (2008). Ecological studies on the ichthyoplankton of coral reef fishes in Hurghada, Red Sea, Egypt. Ph D thesis. Mar. Sci. Dept., Fac. Sci., Suez Canal Univ., 225 pp.

Abu El-Regal, M.A. (2009). Spatial distribution of larval fish assemblages in some coastal bays along the Egyptian Red Sea coast. J. Egypt. Acad. Soc. Environ. Develop., 10 (4): 19-31. 
Abu El-Regal, M.A. (2012). Larval development of two atherinid fish species from the Red Sea, Egypt. Egypt. J. Aquat. Biol. \& Fish., 16 (1): 61 - 71

Abu El-Regal, M.A. (2013a). Adult and larval reef fish communities in coastal reef lagoon at Hurghada, Red Sea, Egypt. Int. J. Environ. Sci. \& Eng., (4):39-49

Abu El-Regal, M.A. (2013b). Spawning seasons, spawning grounds and nursery grounds of some Red Sea fishes. Global J. Fish. Aquat. Res., 6 (6): 126-140.

Abu El-Regal, M.A. (2014). Impact of the valley flooding upon the abundance and diversity of the reef fishes in Wadi El-Gemal protected area, Red Sea, Egypt. J. Aquat. Biol. \& Fish., 18 (1): 83- 95.

Abu El-Regal, M.A.; Ahmed, A.I.; El-Etreby, S.G.; El-Komi, M. and Elliott, M. (2008a). Abundance and diversity of coral reef fish larvae at Hurghada, Egyptian Red Sea. Egypt. J. Aquat. Biol.\& Fish., 12 (2): 17-33.

Abu El-Regal, M.A.; Ahmed, A.I.; El-Etreby, S.G.; El-Komi, M. and Elliott, M. (2008b). Influence of ecological guilds of coral reef fishes on the distribution of their larval near coral reefs at Hurghada, Egyptian Red Sea. Egypt. J. Aquat. Biol. \& Fish., 12(2): 35-50

Ahlstrom, E.H. (1971). Kinds and abundance of fish larvae in the eastern tropical Pacific, based on collections made on EASTROPAC I. Fish. Bull. 69 (1): 3-77.

Ahlstrom, E.H. (1972). Kinds and abundance of fish larvae in the eastern tropical Pacific on the second multivessel EASTROPAC survey and observations on the annual cycle of larval cycle of larval abundance. Fish. Bull. 70 (4):1153-1242.

Borges, R.; Ben-Hamadou, R.; Chicharo, P. and Goncalves, E.J. (2007). Horizontal spatial and temporal distribution patterns of nearshore larval fish assemblages at a temperate rocky shore. Estuarine, Coast. Shelf Sci., 71: 421-428.

Brogan, M.W. (1994). Distribution and retention of larval fishes near the reefs in the Gulf of California. Mar. Ecol. Prog. Ser., 115: 1-13.

Clark, T. (1991). Larvae of nearshore fishes in oceanic waters near Oahu, Hawaii. NOAA Technical report NMFS 101: 1-19.

Cuschnir, A. (1991). Taxonomic Diversity, Biological and Ecological Interspecific Relationships, and Annual Cycle of Distribution of Ichthyoplankton in the Northern End of the Gulf of Elat (Red Sea). Ph.D. Thesis.

Cushing, D.H. (1990). Plankton production and year class strength in fish populations: an update of the match/mismatch hypothesis. In: Blaxter, J.H., Southward, A.J. (Eds.), Advances in Marine Biology, Vol. 26. Academic Press, San Diego, pp: 249-293.

Dytham, C. (2003). Choosing and Using Statistics. A Biologist's Guide. Blackwell Publishing, Oxford, 248 pp.

El-Sherbiny, M.M. (1997).Some ecological studies on zooplankton studies in Sharm El-Sheikh area (Red Sea). M.Sc. Thesis. Mar. Sci. Dept., Fac. Sci., Suez Canal Univ., Egypt., 151 pp.

Faroukh, T.J. (2001). Studies on taxonomy and ecology of some fish larvae from the Gulf of Aqaba. M.Sc. Thesis. Fac. of Grad. Stud., Univ. of Jordan.,103 pp.

Fuiman, L. and Werner, A. (2002). Special considerations of fish eggs and larvae. In: Fuiman, L., Werner, R.G. (Eds.), Fishery Science. The Unique Contributions of Early Life Stages. Fishery Blackwell Publishing. pp: 206-221.

Johannes, R.E. (1978). Reproduction strategies of coastal marine fishes in the tropics. Environ. Biol. Fish., 3: 141-160.

Lazzari, M.A. (2001). Dynamics of larval fish abundance in Penobscot Bay, Maine. Fish. Bull., 99: 81-93. 
Leis, J.M. (1982). Nearshore distributional gradients of larval fish (15 taxa) and planktonic crustaceans (6 taxa) in Hawaii. Mar. Biol., 77: 89-97.

Leis, J.M. (1986).Vertical and horizontal distribution of fish larvae near coral reefs at Lizard Islands, Great Barrier Reef. Mar. Biol., 90: 505-516

Leis, J.M. (1991a). The pelagic stage of reef fishes: The larval biology of coral reefs. In: Sale, P.F. (Ed.), The Ecology of Fishes on Coral Reefs. Academic Press, pp: $183-230$

Leis, J.M. (1991b).Vertical distribution of fish larvae in the Great Barrier Reef lagoon, Australia. Mar. Biol., 109: 7-166.

Leis, J.M. and Carson-Ewart, B.M. (2002). Larvae of Indo-Pacific coastal fishes. An identification guide to marine fish larvae. (Fauna Malesiana Handbooks 2). E. J. Brill, Leiden, 850 pp.

Leis, J.M. and Goldman, B. (1987). Composition and distribution of larval fish assemblages in the Great Barrier Reef Lagoon near Lizard Island, Australia. Australian J. Mar. \& Freshwater Res., 38 (2): 211-223.

Leis, J.M. and McCormick, M.I. (2002). The biology, behaviour, and ecology of the pelagic larval stage of coral reef fishes. In: Sale, P.F. (Ed), Coral Reef Fishes: Dynamics and Diversity in a Complex Ecosystem. Academic Press, San Diego. Pp: 171-199.

Leis, J.M. and Rennis, D.S. (1983). The Larvae of Indo-Pacific Coral Reef Fishes. New South Wales Univ. Press, Sydney, Australia. 269 pp.

Leis, J.M., Hay, A.C. and Trnski, T. (2006). In situ ontogeny of behaviour in pelagic larvae of three temperate marine demersal fishes. Mar. Biol., 148: 655-669.

Montgomery, J.C.; Nicholas, T. and Haine, O.S. (2001). Active habitat selection by presettlement reef fishes. Fish and Fisheries, (2): 261-277.

Moser, H.G., \& Smith, P.E. (1993). Larval fish assemblages of the California Current Region and their horizontal and vertical distributions across a front. Bull. Mar. Sci., 53: 645-691.

Nellen, W. (1973). Kinds and abundance of fish larvae in the Arabian Sea and the Persian Gulf In: Zeitzschel B. (Ed.), The Biology of The Indian Ocean. New York. Pp: 415-430.

Paris, C. and Cowen, R.k. (2004). Direct evidence of biophysical retention mechanism for coral reef fish larvae. Limn. and Ocean. 49: 1964-1979.

Pattira L.; Chirat, N.; Paitoon, P.; Jalilur, R.; Aung, U.H. and Aung, U.W. (2012). Composition, Abundance and Distribution of Fish Larvae in the Bay of Bengal. The Ecosystem-Based Fishery Management in the Bay of Bengal.

Rutherford, E.S. (2002). Fishery management. In: Fuiman, L. Werner, R.G. (Eds.), Fishery Science. The Unique Contributions of Early Life Stages. Fishery Blackwell Publishing. Pp: 206-221.

Smith, C.L.; Tyler, J.C. and Stillman, L. (1987). Inshore Ichthyoplankton: A distinctive assemblage? Bull. Mar. Sci., 41 (2): 432-440

Smith, P.E. and S.L. Richardson (1977). Standard techniques of pelagic eggs and larvae surveys. FAO Fish. Tech. Pap. (175): 1-100.

Suthers, M. and Frank, K.T. (1991). Comparative persistence of marine fish larvae from pelagic versus demersal eggs off south-western Nova Scotia, Canada. Mar. Biol., 108: 175-184

Zar, J.H. (1999). Biostatistical analysis. Fourth Edition. Prentice Hall International (UK), London. 


\section{ARABIC SUMMARY}

الوفرة والتنوع ليرقات أسماك الشعاب المرجانية في خليج مباحث، على ساحل البحر الأحمر المصري

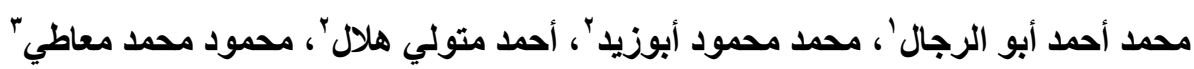

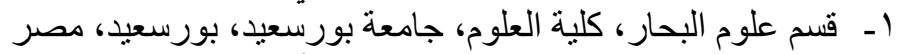

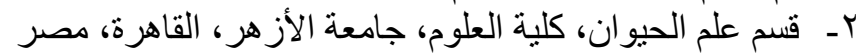

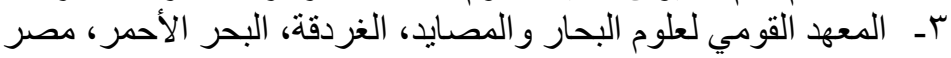

تمت دراسة يرقات أسماك الثعاب المرجانية من أجل تحديد نركيب مجتمع يرقات الأسماك في خليج

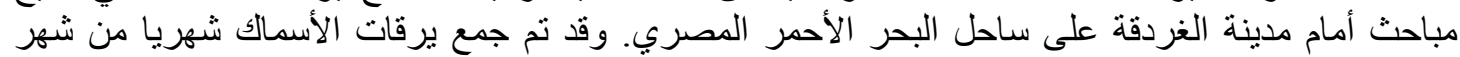

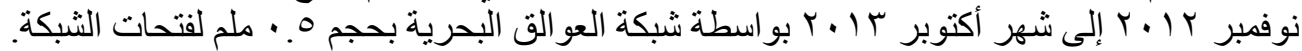

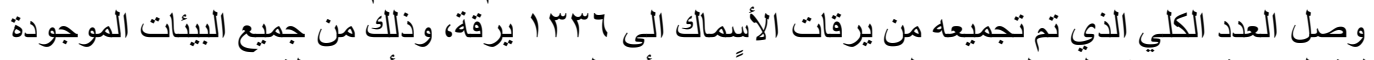

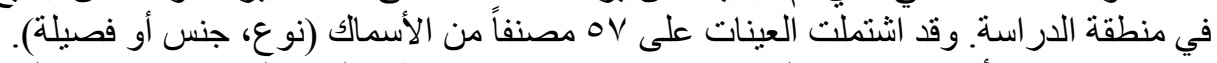

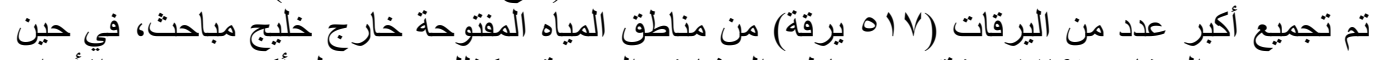

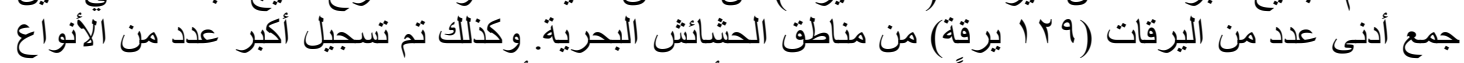

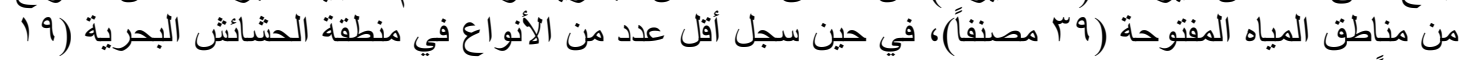

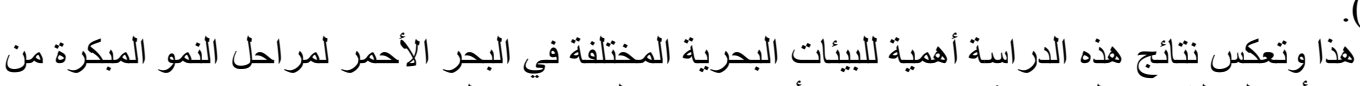
مصنفاً).

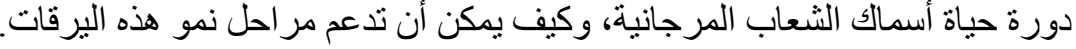

